\title{
The Misuse of Licensing Evidence in Fair Use Analysis: New Technologies, New Markets, and the Courts
}

\author{
Matthew Africa
}

\section{TABLE OF CONTENTS}

Introduction.

I. The Role of Market Effect and Licensing Evidence

in Fair Use Analysis

A. Fair Use Maintains Copyright's Constitutional

Balance

B. The Role of Market Effect in Fair Use Jurisprudence

C. The Use of Licensing Markets as Evidence of Market Effect

II. The Circularity of Licensing Evidence: How Courts Have Struggled in Assessing New Markets

III. How Market Failure Theory Has Over-Simplified Fair Use Analysis.

A. The Influence of Market Failure Theory .

B. The Market Failure Theory Fails to Account for Many Valuable Uses.

C. Market Failure and New Permission Systems

IV. The Current Analysis Does Not Adequately Distinguish

Between Those Uses That Should Be Paid for and Those

That Should Not

A. Market Failure Analysis of New Markets Is Too

Simplistic

B. Strategic Belıavior Warps Fair Use Analysis

V. Proposals to Reform Market Analysis

Copyright $@ 2000$ California Law Review, Inc. California Law Review, Incorporated (CLR) is a California nonprofit corporation. CLR and the authors are solely responsible for the content of their publications.

$\dagger \quad$ J.D., University of California, Berkeley, School of Law (Boalt Hall), May 2000. I wish to thank the following: for his thoughtful and meticulous comments on earlier drafts, Philip Tendler; for his encouragennent and suggestions, Professor Mark Lemley; for their diligent editorial efforts, Mike DeVries, Keith Garner, Jeff Homrig, James Oleson, Julie Pietrantoni, and Sam Sankar; for everything else, my family. 

A. Breathing Space.
1176
B. A Reasonableness Standard
1176
C. Incentive Analysis
1177
D. Shift the Burden of Proof of Market Effect............................... 1178
E. A Trial Period of Exploitation ................................................. 1179
F. Leave the Award of New Markets to Congress ......................... 1179

Conclusion 


\title{
The Misuse of Licensing Evidence in Fair Use Analysis: New Technologies, New Markets, and the Courts
}

\author{
Matthew Africa
}

When confronted with new uses of copyrighted works, courts assessing fair use claims face a difficult problem in examining the fourth fair use factor, the potential effect of the infringing use upon the market for the copyrighted work. A determination that the copyright holder's interest has been harmed implicitly requires a finding that there is a market for the use, and that the holder has a right to prevent unpermitted uses. Often, the very existence of such a market is at issue. In this context, a court's denial of fair use may in effect award a new market to the copyright holder to exploit. Although the determination of whether a new market should belong to a copyright holder is integral to preserving copyright's constitutionally mandated balance between authors and the public, neither the fair use statute nor Supreme Court precedent provides clear standards. As a result, courts have had to strike out on their own. This Comment argues that courts, overly infiuenced by the market failure theory of fair use and misled by licensing evidence, have failed to distinguish between uses that should be paid for and uses that merely can be paid for. Finally, this Comment suggests several methods of reforming fair use analysis of the market effect factor and concludes that, ultimately, Congress may be better suited to preserving copyright's constitutional balance than are the courts.

\section{INTRODUCTION}

Copyright protection has traditionally grown in stuttering steps to protect new uses and forms of copyrighted works. At times, Congress has explicitly extended protections to new media. ${ }^{1}$ In the absence of congressional action, each advance-the photograph, ${ }^{2}$ the sound recording, ${ }^{3}$ the

1. The first copyright statute, the Copyright Act of 1790 , protected only books, maps and charts. See Act of May 31, 1790, ch. 15, \& 1, 1 Stat. 124, 124 (repealed 1802). Over time, the statute has expanded to protect works of visual art, music, choreography, architecture, sound recordings, photography, film, and computer programs, among others. The statute now protects all "original works of authorship fixed in any tangible medium of expression, now known or later developed, from which they can be perceived, reproduced, or otherwise communicated, either directly or with the aid of a machine or device." 17 U.S.C. $\$ 102$ (a) (1994).

2. See Burrow-Giles Lithographic Co. v. Sarony, 111 U.S. 53, 58 (1884) (finding photograph protected by copyright). 
motion picture ${ }^{4}$ - has forced courts to struggle with the scope of copyright protection. Courts have had to make difficult normative judgments about which uses ought to be protected by copyright and which ought to remain in the hands of the public.

As new technologies create new ways to reproduce, manipulate, and distribute copyrighted works, courts applying fair use analysis in copyright infringement cases have struggled with the proper application of the fourth fair use factor: the potential effect of the infringing use upon the market for the copyrighted work. ${ }^{5}$ It is clear that uses that create a market substitute weigh against a finding of fair use. It is less clear, however, that evidence of lost licensing revenues in a new inarket should militate against a finding of fair use, because often the very existence of such a inarket is at issue. A determination that the owner' $s^{6}$ copyright interest has been harmed implicitly requires a finding that there is a inarket, and that she has a right to prevent others from the unlicensed use of her copyrighted work in the new inarket.

In several recent cases, courts have accepted evidence of lost licensing revenues as an indication of harm to the unarket for the copyrighted work. However, in these cases it was debatable whether there was even a inarket for the use of the copyrighted work. ${ }^{7}$ Influenced by the market failure theory of fair use, which posits that the fair use defense should protect only those uses for which a socially beneficial transfer of rights would not occur absent a finding of fair use, these courts have found against fair use. That is, the courts were persuaded that the alleged infringer could have obtained a license to use the work through the open inarket. Underlying the judicial determination of inarket effect is a substantial problem of circularity in assessing the relevant market. As numerous commentators have pointed out, because courts engage in fair use analysis only after finding an infringeinent of a plaintiff's copyright, there is always an act of copying that, at least in theory, could have been licensed. ${ }^{8}$ However, it is a mistake

3. See White-Smith Music Publ'g Co. v. Apollo Co., 209 U.S. 1, 18 (1908) (denying copyright protection to sound recordings in piano rolls).

4. See Edison v. Lubin, 122 F. 240, 242 (3d Cir. 1903) (finding motion picture protected by copyrigbt).

5. The other factors are the purpose and character of the use, the nature of the copyrighted work, and the amount and substantiality of the portion used. See 17 U.S.C. $\$ 107$ (1994).

6. Throughout this Comment, I refer to parties who control copyrights variously as "owners," "copyright holders," and "authors." It is necessary to distiuguish authors from copyright owners and holders because authors of copyrighted material frequently transfer rights to other parties, who may assert legal claims of their own, and because portions of this Comment discuss the incentive rationale of copyright, which concerns authors only. I use "copyright owners" and "holders" interchangeably.

7. See, e.g., American Geophysical Union v. Texaco Inc., 60 F.3d 913 (2d Cir. 1994). This case is discussed infra in Part II.

8. See, e.g., 4 Melville B. Nimmer \& David Nimmer, Nimmer ON Copyright § 13.05[A][4], at 13-182 (1999) [hereinafter 4 NIMMER] ("A danger of circularity is posed here-a potential inarket, no matter how unlikely, has always been supplanted in every fair use case, to the cxtcnt that the 
to think that just because a use could have been licensed it should have been licensed. Situations such as these have arisen frequently in recent years and, doubtless, will spring up even more often as the geometric growth of technology spawns new forms and new media. ${ }^{9}$ Courts must be able to distinguish between uses that should belong to the owner and those that should belong to the public.

Fair use is concerned with the fringe of copyright protection. Although it is commonly seen as a system that carves out exceptions to the owner's monopoly, fair use analysis can also grant rights to the copyright owner: where a use is denied fair use treatment, the use becomes the copyright owner's to exploit. A denial of fair use may legitimize the owner's right to control a new market for the copyrighted work and may force subsequent users to seek a license for similar uses or face liability. Although commentators have argued both for ${ }^{10}$ and against ${ }^{11}$ an expansive treatınent of copyright holders' rights, no one has advanced a primcipled test for determining when a market should be granted to the author.

Such a determination has serious consequences. The constitutional command " $[t] 0$ promote the Progress of Science and the useful Arts, by securing for limited Times to Authors and Inventors the exclusive Right to their respective Writings and Discoveries"12 creates a delicate balance between the rights of authors and those of users and subsequent authors. Denying authors too much nray diminish their incentives to create valuable new works. An author who cannot profit front her creation may not want, or even be able, to produce the new works of art, literature, or nusic that enrich our lives. On the other hand, granting authors too broad a right may not serve the public. For instance, construing an author's rights too broadly may interfere with the creation of new works by fencing off the raw

defendant, by definition, has made some actual use of plaintiff's work, which use could in turn be defined as the relevant potential market."); accord Pierre N. Leval, Toward a Fair Use Standard, 103 HaRv. L. Rev. 1105, 1124-25 (1990); William F. Patry \& Shira Perlmutter, Fair Use Misconstrued: Profit, Presumptions, and Parody, 11 CARDozo ARTs \& ENT. L.J. 667, 688 (1993).

9. See generally I. Trotter Hardy, Copyright and "New-Use" Technologies, 23 Nova L. Rev. 659 (1999) (describing the problems new technologies present in assessing new markets).

10. See, e.g., PaUl Goldstein, Copyright's Highway: From Gutenberg to the Celestial JukEBox (1994); Tom W. Bell, Fair Use vs. Fared Use: The Impact of Automated Rights Management on Copyright's Fair Use Doctrine, 76 N.C. L. Rev. 557 (1998); Jane C. Ginsburg, Authors and Users in Copyright, 45 J. Copyright Soc'Y U.S.A. 1 (1997); Wendy J. Gordou, Fair Use as Market Failure: A Structural and Economic Analysis of the Betamax Case and Its Predecessors, 82 CoLUM. L. REV. 1600 (1982); Robert P. Merges, The End of Friction? Property Rights and Contract in the "Newtonian" World of On-Line Commerce, 12 BeRKELEY TECH. L.J. 115 (1997).

11. See, e.g., Julie E. Cohen, Lochner in Cyberspace: The New Economic Orthodoxy of "Rights Management", 97 Mrch. L. Rev. 462 (1998); Lydia Pallas Loren, Redefining the Market Failure Approach to Fair Use in an Era of Copyright Permission Systems, 5 J. INTELL. Prop. L. 1 (1997); Stewart E. Sterk, Rhetoric and Reality in Copyright Law, 94 MrcH. L. REv. 1197 (1996); Lloyd L. Weinreb, Fair Use, 67 FordhaM L. Rev. 1291 (1999); Pamela Samuelson, The Copyright Grab, WIRED, Jan. 1996, at 134.

12. U.S. CoNST. art I, $\S 8, \mathrm{cl} .8$. 
materials subsequent authors need to fashion new works. If consumers and subsequent authors are demied reasonable access to copyrighted material, society does not fully benefit from the work. Maintaining a proper balance between the rights of owners and users is essential to guarantee that copyright serves its purpose of both stirring creation and encouraging public enjoyment of new works.

This Comment will argue that fair use analysis as currently employed fails to preserve this balance in its analysis of new markets. Overly influenced by market failure theory and misled by evidence of licensing practices, courts have failed to distinguish between markets that should belong to authors and those that should not. This Comment argues that the distinction is a complex one, and because of the many policy determinations involved in drawing the distinction, Congress may be better suited than the courts to decide which markets should and should not belong to authors.

Part I of this Comment addresses the purpose of fair use and the role of licensing evidence in fair use analysis. It shows that neither the Copyright Act nor Supreme Court precedent provides clear standards for assessing whether or not new markets belong to authors. It further explores how the demial of a fair use can award new markets to authors. Part II examines the problem of circularity in evidence of new markets and demonstrates how courts have struggled in assessing new markets. Part III discusses the prevailing view of fair use, the market failure theory, which suggests an expansive treatment of owners' rights. It shows how the market failure theory fails to account for many valuable uses of copyrighted works. Part IV demonstrates that, as applied to licensing, the market failure theory grants too broad a monopoly to owners. It further shows that, because evidence of licensing activity is often warped by strategic behavior, courts are unable to weed out fair uses from those that infringe the copyright holder's property right.

Fimally, Part V articulates some proposals for better assessing the rights of owners and the rights of the public in new markets. Ultimately, it argues that because of the difficulty of the normative judgments involved, courts should exercise restraint, deferring to Congress where a denial of fair use would allow the author to exploit the copyrighted work in a nontraditional medium. This Part concludes that doing so is feasible and may best retain the constitutionally mandated balance between the rights of creators of copyrighted works and the rights of the public.

I

The Role of Market EfFect and Licensing Evidence in FaIr Use ANALYSIS

Before addressing the narrower issue of licensing, it is essential to begin with an understanding of fair use's place in copyright law. This Part 
first explains how the fair use defense maintains copyright's constitutional balance. It then discusses the role that the market effect factor plays in fair use analysis. Lastly, it shows how the scope of market effect recogmized under the statute is ill-defined. It argues that the fair use statute and Supreme Court precedent fail to advance any clear standards for determining the scope of an author's rights im potential markets.

\section{A. Fair Use Maintains Copyright's Constitutional Balance}

The purpose of copyright law is to encourage the creation and dissemination of works to the public. It does so by creating an mcentive for authors to create and distribute works. Copyright creates this incentive by granting authors the exclusive right to do or authorize a number of things: reproduce, distribute, publicly perform, and display the work. ${ }^{13}$ It also provides the author with a zone of expansion around the work by giving the author the exclusive right to prepare or authorize derivative works, ${ }^{14}$ or those based upon the work in "any ... form in which a work may be recast, transformed, or adapted." ${ }^{15}$ Between the owner's right of reproduction and right to create derivative works, the copyright owner presumptively has broad rights in new media.

Like real property law, copyright grants the author broad rights to exclude the public from the use of her property. With certain exceptions, ${ }^{16}$ a copyright owner can set whatever price she wishes for the use of any of these exclusive rights, even if that price is high enough to prevent distribution to the public altogether. ${ }^{17}$ In exchange for these rights the public

13. See 17 U.S.C. $\$ 106(1994)$.

14. See id.

15. 17 U.S.C. $\$ 101$ (1994).

16. The Copyright Act of 1976 provides for compulsory licenses in a number of settings: recording and distribution of nondramatic musical works, see 17 U.S.C. § 115 (1994), reproduction of visual artworks in noncommercial broadcasting, see 17 U.S.C. § 118 (1994), and retransmission by superstations and network stations for private home viewing. See 17 U.S.C. \& 119 (1994). In each case, the rate for the use is determined by the Copyright Office. Each of these exceptions to the general rule of copyright owner autonomy represents an example either of congressional intent to ease transaction costs associated with use of a copyrighted work or to prevent a monopoly on valuable uses. See H.R. REP. No. 94-1476, at 89 (1976) ("TIt would be impractical and burdensome to require every cable system to negotiate with every copyright owner whose work was retransmitted by cable system."); see also 2 Melville B. Nimmer \& David NimMer, NimMer ON COPYRIGHT \& 8.04[A], at 8-53 (1999) [hereinafter NIMMER] (claiming that the compulsory license for nondramatic musical works was created to prevent the "emergence of 'a great musical monopoly"). Implicit in Congress's provision for a compulsory license is a determination that, while the copyright owner should not be able to control certain uses of a copyrighted work, she should nonetheless be compensated for those uses.

17. Copyright owners have attempted to use copyright to censor information with mixed results. Compare Salinger v. Random House, Inc., 811 F.2d 90 (2d Cir. 1987), cert. denied, 484 U.S. 890 (1987) (denying fair use of quotations from unpublished letters in a biography), with Rosemont Enters. v. Random House, Inc., 366 F.2d 303 (2d Cir. 1966) (finding fair use of copyrighted articles in biography of Howard Hughes). 
receives a broader selection of works and public ownership upon expiration of copyright. Copyright also benefits the public by ensuring a robust market for speech. ${ }^{18}$

Fair use is the last refuge of a copyright infringer. A court engages in fair use analysis only after it has found an infringement of the copyrighted work. Thus, fair use arises only after a user has had a chance to assert a number of defenses: the idea-expression dichotomy, merger, de minimis, the origmality requirement, independent creation, the first sale doctrine, and expired or invalid copyright. In each case in which a defense is asserted successfully, the use is excused because it takes an unprotectable element of the work - a portion that remains in, or has reverted to, the public domain. ${ }^{19}$

A fair use represents an exception to the copyright owner's exclusive rights. Under the binary structure of fair use, a use is either fair or infringing. ${ }^{20}$ Fair use encroaches on the rights of authors in two ways. First, a finding of fair use removes the work from the sphere of the author's control: she cannot prevent fair uses, even ones that are objectionable to her. Thus, for example, we allow quotation of a work in a scathing review without the author's permission. Second, a finding of fair use removes a particular use of the work from the author's sphere of economic exploitation: the author cannot charge for the use, no matter how valuable it is. However, fair use is not an absolute abrogation of the copyright holder's rights, as it attempts to give the user only as much as is fair. ${ }^{21}$ Some say fair use represents the author's implied consent to reasonable use. ${ }^{22}$ Alternatively, a fair use may be seen not as an encroachment on the rights

18. "II]t should not be forgotten that the Framers intended copyright itself to be the engine of free expression." Harper \& Row, Publishers, Inc. v. Nation Enters., 471 U.S. 539, 558 (1985). Several authors have recently addressed the role of copyright protection in shaping the public discourse. See, e.g., Yochai Benkler, Free As the Air to Common Use: First Amendment Constraints on Enclosure of the Public Domain, 74 N.Y.U. L. Rev. 354 (1999); Neil Weinstock Netanel, Copyright and $a$ Democratic Civil Society, 106 YALE L.J. 283 (1996).

19. The public domain is "a commons that includes those aspects of copyrighted works which copyright does not protect." Jessica Litman, The Public Domain, 39 EmoRY L.J. 965, 968 (1990).

20. The statute provides as follows: "[T] he fair use of a copyrighted work ... is not an infringement." 17 U.S.C. $\$ 107$ (1994).

21. For example, in Campbell v. Acuff-Rose Music, Inc., 510 U.S. 569 (1994), the Supreme Court remanded to determine if the defendants had copied so much of the work as to undermine the market for non-parody derivative works that the owner might license. See id. at 582,595 .

22. See, e.g., Harper \& Row, 471 U.S. at 549-50; Gordon, supra note 10, at 1616; see also GoldSTE1N, supra note 10, at 85 ("If copyright owners regularly acquiesce in certain copies or quotations made by others, that alone is evidence that the use is reasonable and fair."). However, numerous scholars have questioned this notion. See, e.g., Mark A. Lemley, The Economics of Improvement in Intellectual Property Law, 75 Tex. L. Rev. 989, 1077 n.394 (1997) ("The absurd implication of this theory is that in any case important enough to be litigated, fair use should never apply!"). 
of an owner, but rather as a use that does not belong to the owner to begin with. ${ }^{23}$

The preamble to the fair use statute describes several prototypical examples of fair use: "the fair use of a copyrighted work . . . for purposes such as criticism, comment, news reporting, teaching (includimg multiple copies for classroom use), scholarship, or research, is not an infringement."24 A use for any of these purposes is not automatically fair, as demonstrated by the use of the qualifier "fair" in the sentence, ${ }^{25}$ but they do represent commonly accepted exceptions to the rights of copyright holders.

Implicit in the binary structure of the fair use inquiry is the policy that society benefits when some uses of copyrighted works require neither permission from nor payment to an author: there are certain markets that the copyright owner should not be allowed to control by denying use or by charging others for licenses to use the copyrighted work. The next section explores the role the market effect factor plays im courts' determinations of whether a given use of a copyrighted work requires the sanction of the copyright holder.

\section{B. The Role of Market Effect in Fair Use Jurisprudence}

The Copyright statute sets forth four factors that courts must consider in making a fair use determination. ${ }^{26}$ Although the statute does not assign weight to the four factors, courts have often given the last of these, the market factor, disproportionate weight in fair use analysis. In Harper \& Row Publishers, Inc. v. Nation Enterprises, ${ }^{27}$ the Supreme Court went so far as to state that "[t]his last factor is undoubtedly the single most important element of fair use. ${ }^{, 28}$ Until Campbell v. Acuff-Rose Music,

23. "The uses that are mentioned as examples of fair use in the statute are... simply uses that, for one reason or another, we do not regard as clearly within the author's right." Weinreb, supra note 11 , at 1301. But see Ginsburg, supra note 10, at 12 ("IP]rivate copying is not so much a 'right' as an activity tolerated in the absence of effective enforceinent.").

24. 17 U.S.C. § 107 (1994).

25. See Princeton Univ. Press v. Michigan Document Servs., 99 F.3d 1381, 1385 n.1 (6th Cir. 1996) (en banc).

26. The statute reads:

In determining whether the use made of any work in any particular case is a fair use the factors to be considered shall include-

(1) the purpose and character of the use, including whether such use is of a commercial nature or is for nonprofit educational purposes;

(2) the nature of the copyrighted work;

(3) the amount and substantiality of the portion used in relation to the copyrighted work as a whole; and

(4) the effect of the use upon the potential market for or the value of the copyrighted work. 17 U.S.C. \& 107 (1994).

27. 471 U.S. 539 (1985).

28. Id. at 566 (citing 4 NIMMER § 13.05[A], at 13-76). 
Inc. ${ }^{29}$ many lower courts followed this pronouncement rigidly and diligently. ${ }^{30}$

The Campbell decision represents a watershed in fair use jurisprudence. In that case, the copyright holder of the Roy Orbison composition "Pretty Woman" sued the musical group 2 Live Crew, which had recorded a rap version of the song. The district court granted 2 Live Crew summary judgment, holding that its song was a parody that made fair use of the original song. ${ }^{31}$ The appellate court reversed; its holding seemed largely driven by its findings regarding the commerciality of the 2 Live Crew recording and a resulting presumption of harm to the copyright holder's market. ${ }^{32}$ In upholding 2 Live Crew's uncompensated use as fair, the Court rejected the Sixth Circuit's heavy emphasis on the commerciality of the new recording and, implicitly, the court's reliance on the market effect factor. ${ }^{33}$ The Court pointedly omitted any reference to the dominance of the fourth factor. ${ }^{34}$ The Court instead extolled transformative use-the notion that a fair use should create some improvement that further benefits the public. ${ }^{35}$ The Campbell opinion has been warmly received by commentators. $^{36}$

However, despite Campbell's implicit diminution of the market effect factor, its influence persists in many decisions. One circuit has subsequently treated it as first among equals. ${ }^{37}$ Other courts continue to cite the Harper language without qualification. ${ }^{38}$ Other courts allude to the Harper

29. 510 U.S. 569 (1994).

30. See Pierre N. Leval, Nimmer Lecture: Fair Use Rescued, 44 UCLA L. Rev. 1449, 1459 (1997) ("This observation was dictum; it played no role in the justification of the holding. But dictum uttered by a high court is followed as if it had been a holding.").

31. See Acuff-Rose Music, Inc. v. Campbell, 754 F.Supp. 1150, 1158-59 (M.D. Tenn. 1991).

32. See Acuff-Rose Music, Inc. v. Campbell, 972 F.2d 1429, 1436-37, 1438-39 (6th Cir. 1992).

33. See Campbell, 510 U.S. at 591.

34. See Castle Rock Entertainment, Inc. v. Carol Publ'g Group, Inc., 150 F.3d 132, 145 (2d Cir. 1998) (noting that "[t]he Supreme Court has recently retreated from its earlier cases suggesting that the fourth statutory factor is the most important element of fair use").

35. "The central purpose of this investigation is to see, in Justice Story's words, whether the new work 'merely supersede[s] the objects' of the original creation or instead adds something new, with a further purpose or different character, altering the first with new expression, meaning or message." Campbell, 510 U.S. at 579 (internal citations omitted). The tcrm "transformative use" is generally credited to Judge Pierre N. Leval, who advanced his ideas in a thoughtful and influential piece, Toward a Fair Use Standard. See generally Leval, supra note 8. Althougl the doctrine of transformative use secms to reign currently, at least one author lias argued that the application of transformative use fails to provide any clear or predictable results. See generally Diane Leenlieer Zimmerman, The More Things Change the Less They Seem "Transformed": Some Reflections on Fair Use, 46 J. COPYRGHT Soc'Y U.S.A. 251 (1998).

36. See, e.g., Leval, supra note 30, at 1464 ([Campbell is] "the finest opimon ever written on the subject of fair use").

37. See Princeton Univ. Press v. Michigan Document Servs., 99 F. $3 d$ 1381, 1385 (6th Cir. 1996) (en banc) ("We take it that this factor . . . is at least prinus inter pares.").

38. See, e.g., Sundeman v. Seajay Soc'y, Inc., 142 F.3d 194, 206 (4th Cir. 1998); Triad Sys. Corp. v. Southeastern Express Co., 31 U.S.P.Q.2d 1239, 1245 (N.D. Cal. 1994). 
pronouncement and qualify it, ${ }^{39}$ but one suspects that they still give it weight-why else, after all, would they mention it? The next section will show that despite the importance, if not doiminance, of the market effect factor, the scope of market effect is ill defined. It will argue that the fair use statute and Supreme Court precedent fail to articulate any clear test for determining the extent of an author's rights in potential markets.

\section{The Use of Licensing Markets as Evidence of Market Effect}

The fair use statute provides that courts shall consider "the effect of the [allegedly infringing] use upon the potential market for or value of the copyrighted work" when engaging in a fair use analysis. ${ }^{40}$ The "value of" clause should not be read too literally, for to do so would bar some of the prototypical fair uses. Take for instance a quotation from a work in a scathing review-presumably, this use would affect both the value of and the potential market for the work, because if everyone is convinced the work is bad, no one will want the work or license its use. Nonetheless, such quotation is unquestionably fair: the author's harm is not cognizable because to deny the use would prevent the public's enjoyment of the work by unnecessarily limiting free speech. ${ }^{41}$ Copyright only protects against injuries from uses that the owner has a right to control. Where the owner has no such right, harm to a inarket is irrelevant to the fair use analysis.

Whether the "potential market" alluded to in the statute includes the contested use of a work is often at issue in fair use cases. Although the plain language of the statute, by using the word "potential," indicates that copyright law recoginizes injuries to some inarkets that the owner has not entered, it does not clearly state how far protection can or should extendafter all, it is hard to think of any market that is not in soine sense "potential." The Supreme Court laid out a test for assessing harm to untested markets for copyrighted works when it considered consumers' use of VCRs to tape television prograins in Sony Corp. v. Universal Studios, Inc. ${ }^{42}$ There, the Court ruled that market harm is demonstrated by

proof either that the particular use is harmful, or that if it should become widespread, it would adversely affect the potential market for the copyrighted work. Actual present harm need not be shown; such a requirement would leave the copyright holder with no defense against predictable damage. Nor is it necessary to show

39. See, e.g., American Geophysical Union v. Texaco Inc., 60 F.3d 913, 926 (2d Cir. 1994).

40. 17 U.S.C. \& 107(4) (1994).

41. See Campbell v. Acuff-Rose Music, Inc., 510 U.S. 569, 591-92 (1994) ("[W] hen a lethal parody, like a scathing theater review, kills demand for the original, it does not produce a harm cognizable under the Copyright Act."). But cf. Chicago School Reform Bd. of Trustees v. Substance, Inc., 79 F. Supp. 2d 919 (N.D. Ill. 2000), in which a court recognized harm to the value of copyrighted tests themselves (rather than a market for thein) when the defendant published thein in his newsletter.

42. 464 U.S. 417 (1984). 
with certainty that future harm will result. What is necessary is a showing by a preponderance of the evidence that some meaningful likelihood of future harm exists. ${ }^{43}$

While this test demonstrates that copyright protects certain markets that an owner has not yet entered, it does not tell us which harms should be recognized. Does "potential market" embrace any market subsequently discovered or simply those that the author has or had an expectation of exploiting? It is helpful to enumerate types of markets in an attempt to distinguish those that typically belong to the author and those in which fair use would likely be upheld.

In the simplest case, a defendant's use of an owner's copyrighted material provides a market substitute for the work or a licensed derivative. In this mstance, harm to the owner's market is obvious because the use is piracy, and no serious claim of fair use can be made. Thus if I make copies of your film and begin distributing it in competition with you, I have infringed your rights of reproduction and distribution. This use could not legitimately be called fair.

The problen is slightly less one-sided where a defendant appropriates copyrighted material but adds significant value. The defendant's creation may supersede the owner's, but it is less a naked substitute than an improventent. Despite this, it is also likely an infringement of the copyright holder's right to prepare derivative works, among others. ${ }^{44}$ Suppose I prepare and sell a book of trivia questions based on your popular television show. ${ }^{45}$ While I may have added substantially to the value of the new work through my selection and arrangement of your characters or plot elements, or by creating new material such as wrong answers, I have infringed your right to prepare and distribute derivative works. If my use is "transformative" enough under the rubric of Campbell, I may evade liability through a fimding of fair use. However, a court may also conclude that I am a free-rider for attempting to proceed without a license.

It is more difficult to determine whether a copyright holder should control the new market where the alleged infringer uses copyrighted expression in a market that the copyright holder might not enter. The court must determine prospectively whether the copyright holder should control the market and if so, whether requiring a license is appropriate. As noted above, Campbell clarified this market analysis somewhat by pronouncing that "[t]he market for potential derivative uses includes only those that creators of original works would in general develop or license others to

43. Id. at 451 .

44. See generally Lemley, supra note 22 (explaining and criticizing the allocation of rights in derivative works under copyright).

45. The facts I suggest are based on Castle Rock Entertainment v. Carol Publ'g Group, Inc., 150 F.3d 132 (2d Cir. 1998) (holding that the use of characters and plot elements in defendant's Seinfeld Aptitude Test was not fair). 
develop." ${ }^{946}$ In the context of Campbell this distinction made sense because Campbell concerned a parody: parody is an existing market that owners typically do not try to enter or license, and thus the Court's statement clearly excludes it ${ }^{47}$ However, when it is less evident whether a copyright holder would or would not enter the new market, the Campbell formulation is somewhat mcoherent.

While defining the owner's market as uses that she "would im general develop or license others to develop" clearly extends copyright protection to common or foreseeable derivative uses, it creates a rather vague standard for those that are less so. Does the phrase "would in general develop or license others to develop" imply that the Court was referring to uses an owner would generally market or solicit? For example, a letter to the editor is seldom developed or licensed for development as an opera, so authors don't generally try to license them in that fashion. What of markets a copyright holder does not wish to pursue? At least one court has read a copyright holder's lack of interest in entering a market to imply that the user did not harm the holder. ${ }^{48}$

What of a new or speculative market? Suppose I posted a copyrighted nervs article to a website for discussion with visitors to the site; the newspaper from which I took the article imght publish an on-line version, but arguably my version serves a different market than the newspaper's does. ${ }^{49}$ Although newspapers generally provide a forum for discussing issues raised by their news coverage, letters to the editor, that forum is qualitatively different. Whereas newspapers often appeal to a general readership, a website might attract a narrower following that is likely to share a set of

46. Campbell, 510 U.S. at 592.

47. Of course, this formulation leaves plenty of room for argument about whether a given use is actually a parody, which mocks the original work and thus must borrow from it, or satire, which utilizes the original work merely to lampoon some other object. Compare Campbell, 510 U.S. at 569, with Dr. Seuss Enters., L.P. v. Penguin Books USA, Inc., 109 F.3d 1394 (9th Cir. 1997) (denying fair use of The Cat in the Hat in morbid children's book version of the O.J. Simpson story). For perhaps the funniest parody case, see Lyons Partnership, LP. v. Giannoulas, 14 F. Supp. 2d 947 (N.D. Tex. 1998) (upholding fair use of Barney character in abusive performance by the Famous Chicken).

48. See Lewis Galoob Toys, Inc. v. Nintendo of Am., Inc., 964 F.2d 965, 971-72 (9th Cir. 1992) (holding that displays created by defendant's Game Genie device constituted a fair use of copyrighted material). This situation may even engender a kind of reverse free-riding where a user discovers a valuable collateral market that the copyright holder later decides to exploit. See, for example, Ty, Inc. $v$. West Highland Publ'g, Inc., No. 98 C 4091, 1998 WL 698922 (N.D. Ill. Oct. 5, 1998), in which the maker of copyrighted Beanie Baby toys did not seek to restrain the reproduction of the toys in The Beanie Baby Handbook until it became perhaps too successful.

49. The facts I suggest are similar to those in a dispute between two newspapers, the Washington Post and the Los Angeles Times, and the host of a Web service called Free Republic. See Pam Mendels, Newspaper Suit Raises Fair Use Issues, CyBERTIMES-N.Y. TIMES Web (Oct. 2, 1998) <http://www.nytimes.com/library/tech/98/10/cyber/articles/02papers.html>. For a discussion of the dispute and the First Amendment concerns involved, see Benkler, supra note 18 at 357. See also Chicago School Reform Bd. of Trustees v. Substance, Inc., 79 F. Supp. 2d 919 (N.D. Ill. 2000) for a case in which the reproduction of copyrighted works to stir debate was denied a fair use finding. 
beliefs or concerns. Some readers might also feel more comfortable expressing their views in a website setting because it allows relative anonymity. Thus, use in a new inarket may raise novel concerns.

What of uses developed after the creation of the work? Granting an author rights in later-developed markets is troubling in light of copyright's incentive function. ${ }^{50} \mathrm{It}$ is hard to see how granting authors new rights after creation spurs additional invention, unless one defines the author's initial right as including the expectation of expansion. ${ }^{51}$ What if the owner wants to license all uses that implicate her work? As discussed above, some uses strongly implicate a user's right of free speech and thus should not be controlled by the copyright owner. As these questions indicate, the Campbell analysis does not adequately explain when an owner has a right to control new uses.

Some markets for new uses of copyrighted works intuitively belong to the author, such as when a new medium is employed as a substitute for or an improvement of a preexisting mediun. Thus it makes sense to allow the owner of a right to make LPs the right to also inake CDs because CDs represent merely another medium of commercial distribution for the sane creative content. Since CDs have largely supplanted the market for LPs, denying the owner the right to exploit this market would deprive the owner of the right to profit from the commercial distribution of her recordings.

On the other hand, there are probably some uses for which markets may never develop, as when a work is reproduced in a useless or unpopular medium. An owner is probably fairly indifferent to the current market for reproductions on piano rolls, eight-track cassettes or Betamax videocassettes, for example. The minimal revenue the owner stands to gain from licensing such uses is probably outweighed by the transaction costs associated with entering into such licensing agreements.

Lastly, there are markets that are unlikely to develop without court intervention, for example those in which the use represents a minor incursion on the owner's right and in which it is difficult for the owner to detect or deter individual violations. In such cases, there may be no established mechamism for the user to obtain permission, and she may either forego the use altogether or proceed without obtaining approval. Photocopying was one such exaunple: froin the introduction of the photocopier in 1960 to the Basic Books, Inc. v. Kinko's Graphics Corp..$^{52}$ case in 1991, no one was ever held liable for systematic copying. In fact, the one time the Suprenre

50. For a blistering criticism of copyright's departure from its incentive function, see Sterk, supra note 11, at 1205 ("Any copyright protection beyond that necessary to compensate the author for lost opportunities would generate no additional incentive to create and would discourage production of additional copies even when the cost of producing those copies was less than the price consumers would be willing to pay.").

51. See Cohen, supra note 11, at 506-08 (arguing that the expansive view of rights is ahistorical).

52. 758 F. Supp. 1522 (S.D.N.Y. 1991). 
Court addressed photocopying, the Court deadlocked and thus let stand a Court of Claims decision upholding library copying as fair use.53 Although a private organization, the Copyright Clearance Center (the "CCC"), had attempted to license photocopy rights, it had only inarginal success before courts began to impose liability on those engaged in photocopying. ${ }^{54}$ However, after the Basic Books decision and others like it, ${ }^{55}$ the CCC may have finally obtained the critical mass necessary to administer a functioning nnarket through the threat of judicial enforcement. ${ }^{56}$

The fair use defense recognizes that the owner of a copyrighted work does not have the right to compensation for or control of every use of that work. Where a court blindly accepts evidence of harm to a licensing nıarket without first considering whether copyright should allow the owner to exploit the licensing inarket in the first place, the court may allow the owner to foreclose coinpetition in all nrarkets, even those to which copyright protection should not extend. Neither the Copyright Act nor the Supreme Court's jurisprudence provides any clear criteria for assessing new markets. Accordingly, courts have had to strike out on their own.

Beyond the vagueness of the statute and fair use jurisprudence, the examination of licensing evidence is further complicated by the allocation of the burden of proof in fair use analysis. Because fair use is an affirmative defense, the user is charged with proving that a use has no effect on the inarket for a copyrighted work. ${ }^{57}$ What evidence can a user possibly enter to show that there is no market for the infringing use? A user cannot prevail by asserting that a use has raised the value of the copyrighted work,

53. See Williams \& Wilkins Co. v. United States, 487 F.2d 1345, 1347 (Ct. Cl. 1973), aff'd by an equally divided court, 420 U.S. 376 (1975).

54. See Kenneth D. Crews, Copyright at a Turning Point: Corporate Responses to the Changing Environment, 3 J. INTELL. PROP. L. 277 (1996) (docunienting the history of the CCC and the response of for-profit companies to recent decisions such as Texaco).

55. See, e.g., American Geophysical Union v. Texaco Inc., 60 F.3d 913 (2d Cir. 1994) (discussed in Part II, infra).

56. See Crews, supra note 54, at 278 ("The Texaco decision has been a high-profile alarm; forprofit companies in many industries throughout the country may now be conipelled to reexamine their habits, practices, assunptions, and policies in light of that decision."). Professor Gordon was perhaps prophetic when she wrote:

At early stages of use, the transaction costs that would be involved for a user to purchase permission to use, or for the copyright owner to seek enforcement against nonpaying users, might well exceed whatever gain the parties might otherwise expect from the transaction. A custom therefore may develop under which users proceed without permission.

As the quantity of use grows, the copyright owners may wish to set up collection and enforcement mechanisms, including such market devices as clearinghouses. In order to persuade users to procced through the device, however, the copyright owners might well need a judicial declaration that the uncompensated use, previously minor and left unfettered, constituted an infringement of copyright.

Gordon, supra note 10, at 1621 (internal citations omitted).

57. See Campbell v. Acuff-Rose Music, Inc., 510 U.S. 569, 590 (1994). 
say by increasing deinand for it. ${ }^{58}$ By contrast, courts have allowed copyright plaintiffs to demonstrate the existence of markets based on bare allegations of intent or willingness to license their works. ${ }^{59}$ While proving a negative is difficult under any circumstances, it is virtually impossible where licensing is concerned, as the next Part describes.

\section{II}

The Circularity of Licensing Evidence: How Courts Have STRUGGLED IN ASSESSING NEW MARKETS

Faced with little guidance from Congress, courts have struggled in assessing new 1narkets. Consider Ringgold v. Black Entertainment Television, Inc. ${ }^{60}$ In that case, artist Faith Ringgold brought suit against a television network that used a poster of her work entitled "Church Picnic Story Quilt" in an episode of the television show ROC. Although the work appeared only briefly, in the background and out of focus, the district court determined that the use could have infringed Ringgold's right of reproduction. ${ }^{61}$ The defendants then asserted the fair use defense. Accordingly, they had the burden of proving, inter alia, that there was no harm to the potential inarket for the work.

The defendants argued that the use had not harmed the market for Ringgold's work and, if anything, might help her poster sales. The district court was persuaded of this, noting that the use did not create a market substitute and would probably not affect her sales of the poster or her ability to license reproductions of the work in other forms. ${ }^{62}$ The finding was further bolstered by two cases upholding the reproduction of artwork on television and film. ${ }^{63}$ Accordingly, the court granted BET's motion for summary judginent.

Ringgold responded by claiming that she was often asked to license her work to films and television and that in 1992 she was asked to license

58. See id. at 590 n.21 ("Even favorable evidence, without more, is no guarantee of fairness. Judge Leval gives the example of the film producer's appropriation of a composer's previously unknown song that turns the song into a commercial success; the boon to the song does not make the film's simple copying fair.") (citation omitted).

59. See infra Part II.

60. 126 F.3d 70 (2d Cir. 1997).

61. See id. at 77.

62. See Ringgold v. Black Entertainment Television, Inc., No. 96 Civ. 0290, 1996 WL 535547, at *4 (S.D.N.Y. Sept. 19, 1996).

63. See Amsinck v. Columbia Pictures Indus., Inc., 862 F. Supp. 1044 (S.D.N.Y. 1994) (finding that display of copyrighted artwork on a mobile in a film did not infringe and was fair use); Mura v. Columbia Broad. Sys., Inc., 245 F. Supp. 587 (S.D.N.Y. 1965) (finding that reproduction of a copyrighted puppet on a television program did not infringe copyright); Jackson v. Warner Bros., Inc., 993 F. Supp. 585 (E.D. Mich. 1997) (finding fair use in depiction of copyrighted lithographs on wall of set in film). 
use of the poster to another sitcom..$^{64}$ Although both statements indicate that Ringgold was mterested in licensing her artwork, neither proves that there was a market for such licensing or that one was likely to develop. Her demands may have been too large or the market's imterest too small to ever complete a transaction; she did not claim to have concluded such a licensmg transaction im the five years between the airing of the show and the trial. Should this not cut against her assertion that there was a inarket for the use $?^{65}$ Is the mere allegation of an attempt to license, even an unsuccessful one, sufficient to demonstrate a market? What of a bare statement of intent to license; is it sufficient to defeat a claim of fair use on this factor? The appellate opinion did not discuss any evidence either that artists routinely licensed their works to television prograns as set decorations or that television prograins obtain licenses for such uses. Instead, the court concluded flatly that such uses should be paid for. ${ }^{66}$ As a result, the appellate court saw a triable issue of fact as to whether a market for licenses to reproduce Ringgold's poster on television existed and reversed the lower court's summary judgment, remanding for renewed consideration of that question. ${ }^{67}$ The appellate court was too quick to conclude that a market for licensing Ringgold's work was possible and that such a market could have been supplanted by BET's use. Any examination of why Ringgold was entitled to exploit the market was notably absent.

Alternatively, consider American Geophysical Union v. Texaco Inc. ${ }^{68}$ in which a sharply divided circuit court panel considered the market for individual photocopies of scholarly articles and the implications of such a market. In that case, a group of copyright holders sued a major oil company alleging that the company's photocopying practices for scientific research systematically infringed the copyrights in the copyright holders' articles. ${ }^{69}$ Although the majority and dissent agreed that copyright holders

64. The appellate court noted that Ringgold "declined because of an inadequate price and inadequate artist's credit." Ringgold, 126 F.3d at 81.

65. Clearly, an owner will not introduce evidence of failed attempts to license a work if she thinks it will be held against her. This means it is unlikely to end up in the record; a user is unlikely to be aware of or be able to prove such a failure absent extraordinary circumstances (for example a mass solicitation).

66. Ringgold, 126 F.3d at 80 . The court stated:

[Just as members of the public expect to pay to obtain a painting or a poster to decorate their hoines, producers of plays, films, and television programs should generally expect to pay a license fee when they conclude that a particular work of copyrighted art is an appropriate Id. component of the decoration of a set.

67. See id. at 81 . The appellate court noted that the district court's fair use analysis was "legally flawed" as to two of the four factors. Id. at 80,81 .

68. 60 F.3d 913 (2d Cir. 1994).

69. To simplify proof, the court considered only the photocopying practices of a single Texaco researcher with respect to a simgle publication, assuming them to be representative of other researchers. See id. at 915. That publication, the Journal of Catalysis, was subject to license froin the CCC. See American Geophysical Union v. Texaco Inc., 802 F. Supp. 1, 7 (S.D.N.Y. 1992). 
should only be entitled to exploit "traditional, reasonable, or likely to be developed markets,"70 they clashed over whether a market for individual copies of scholarly articles even existed. The majority believed that existing clearance mechanisms provided such a market. ${ }^{71}$ The majority cited the availability of licenses through the $\mathrm{CCC}$ and pointed to evidence that numerous large corporations subscribed to the clearance service. ${ }^{72}$ Even so, it conceded that "the participation of for-profit institutions that engage in photocopying has been limited."73 Persuaded of the existence of a market, the majority saw the mechanisms as strong evidence that the contested use should have been licensed. ${ }^{74}$

The dissent questioned these conclusions, ${ }^{75}$ stressing the speculative nature of the potential market for licensed copies: "There is a circularity to the problem: the market will not crystallize unless courts reject the fair use argument . . . but, under the statutory test, we cannot declare a use to be an infringement unless . . . there is a market to be harmed." 76 Faced with a difficult set of facts, the Texaco majority and dissent were responding to different concerns. In effect, the majority asked, "Can the use be paid for?" By contrast, the dissent asked, "Should the use be paid for?"

The dissent was skeptical about evidence even of those large companies that did participate in CCC's licensing mechanism: "Until this case is decided, companies have had little choice but to become licensees or defendants."77 The dissent was wise to question the motives of participants in entering imto CCC licenses. As discussed below, the fact that a use is sometimes paid for does not necessarily mean it should be: a party may seek to license questionable or noninfringing uses out of fear of liability. ${ }^{78}$

70. American Geophysical Union, 60 F.3d at 930 (majority); see also id. at 936 (dissent).

71. See id. at 930 ("[S]ince there currently exists a viable market for licensing these rights for individual journal articles, it is appropriate that potential licensing revenues for photocopying be considered in a fair use analysis.").

72. See id.

73. Id. at 929 n.16.

74. See id. at 931 . The majority observed:

[I] is sensible that a particular unauthorized use should be considered "more fair" when there is no ready market or means to pay for the use, while such an unauthorized use should be considered "less fair" when there is a ready market or means to pay for the use. The vice of Id. circular reasoning arises only if the availability of payment is conclusive against fair use.

75. See id. at 938 (Jacobs, J., dissenting). Judge Jacobs remarked:

The inajority finds it 'sensible' that a use 'should be considered "less fair" when there is a ready market or means to pay for the use.' That view is sensible only to a point. There is no technological or commercial impediment to imposing a fee for use of a work in a parody, or for the quotation of a paragraph in a review or biography. Many publishers could probably Id. unite to fund a bureaucracy that would collect such fees.

76. Id. at 937 (Jacobs, J., dissenting).

77. Id. at 938 (Jacobs, J., dissenting).

78. See infra Part IV.B. 
The evidence of the efficacy of the CCC was particularly troublesome because a license from the CCC provided the user with no gnarantee that the use was authorized. ${ }^{79}$ Although the $\mathrm{CCC}$ represented numerous publishers, only thirty percent of the market for journals was covered by CCC hicenses. ${ }^{80}$ Furthermore, since some of the articles in journals were not protected by copyright, the license arguably allowed the CCC to collect royalties for works that were not covered by copyright. ${ }^{81}$ These royalties represent a wimdfall to $\mathrm{CCC}$, rather than a benefit to either authors or the public.

The court's recognition of a market on these facts raises many questions about permission systems. Is the user obliged to pay into any available scheme for licensing? What if multiple schemes exist? What if a user pays into a clearance mechanism that does not cover the challenged use? ?2 $^{82}$ What of later-developed schemes? The Texaco majority seemed unwilling to entertain Texaco's very legitimate doubts about the viability of the CCC. This failure to scrutimize the available means of market clearance led to a decision that may be held against those who photocopy and perhaps those who engage $\mathrm{m}$ analogous uses.

Further, the demal of fair use may not only legitimize a licensing market, it may create market power. For example, in the Texaco case, the court cited the services of the CCC as evidence of a market, in effect placing the government imprimatur on CCC's services. As discussed above, relatively few who photocopy had adopted CCC's licensing service before the Texaco decision. ${ }^{83}$ Since then use has likely burgeoned..$^{84}$ Would it not be better to let a market develop orgamically? Does a court capriciously create a monopoly when it endorses a given service? ${ }^{95}$ It seems likely that other services that subsequently enter the market are at a

79. As Judge Jacobs observed in dissent, "no CCC license can assure a scientist that photocopying any given article is legal." American Geophysical Union, 60 F.3d at 937 (Jacobs, J., dissenting).

80. See id.

81. See id.

82. For a proposed solution to the circularity of photocopy licensirg, see Brian T. Ster, Note, Photocopying and Fair Use: Exploring the Market for Scientific Joumal Articles, 30 IND. L. REv. 607 (1997) (arguing that a user should be subject to liability for infringement only where a copyright owner participates in a clearanee mechanism).

83. See supra note 54 and accoinpanying text.

84. See supra note 56 and accompanying text.

85. Generally in situations in which the government creates a monopoly (for example, public utilities), the mouopoly is legislatively created, highly regulated, and overseen by administrative agencies to prevent abuse of consumers. A judicially created monopoly would have none of these checks. The inajor performance rights societies, ASCAP and BMI, serve a similar clearance function in the market for musical coinpositious, as discussed in Part IV.A infra. These organizations have been the snbject of numerous antitrust cases and several consent decrees. See generally Cohen, supra note 11 , at 500-01. 
competitive disadvantage. This may prevent competitors from entering the market to provide consumers with better, cheaper service.

Thus the denial of fair use not only affects the infringer, but it can have also unforeseen consequences for potential pioneers and users of new markets. Courts generally resolve doubts about the existence of new markets in favor of the copyright owner, although they are not very good at articulating their reasons for so doing. While partly attributable to the uncertain standards pertaining to new markets, it is also attributable to courts' overreliance on the market failure theory of fair use. The next Part argues that overreliance on the market failure theory produces results that incorrectly favor copyright owners, subverting copyright's constitutional balance between copyright holders and the public.

III

\section{How Market Failure Theory Has Over-Simplified FaIR Use ANALYSIS}

This Part discusses how market failure theory has shaped fair use analysis. It begins by outlining the theory and showing how it has been adopted. Next it shows that the elegance of market failure theory oversimplifies fair use analysis and fails to account for valuable uses of copyrighted works. Lastly, it critiques certain overly optimistic adherents of the market failure theory, who suggest that technological permission systems may obviate fair use altogether.

\section{A. The Influence of Market Failure Theory}

Much has been written about the proper role of fair use in the copyright scheme. While all agree that the purpose of copyright is to encourage creation and dissemination, commentators disagree as to how best to effectuate this purpose. Whose interests prevail in a tug of war between the author, consuniers, and subsequent authors? As discussed in Part I, above, the balance between these coinpeting interests has broad inplications for society.

Although nunerous commentators have offered a variety of visions of the theoretical justifications behind copyright, ${ }^{86}$ one school has dominated

86. Included are those who argue that the terms of copyright should be shaped by its democracyenhancing function, see, e.g., Netanel, supra note 18; those who argue that copyright should reflcct social norms and expectations, see, e.g., Weinreb, supra note 11; those who argue that the expansion of copyright protection is not necessary to drive creation, see, e.g., Glynn S. Lunney, Jr., Reexamining Copyright's Incentives-Access Paradigm, 49 VAND. L. REv. 483 (1996); those who argue that copyright itself is unnecessary to drive creation, see, e.g., Stephen Breyer, The Uneasy Case for Copyright: A Study of Copyright in Books, Photocopies, and Computer Programs, 84 HARV. L. REV. 281 (1970); and anarchists, see, e.g., John Perry Barlow, A Cyberspace Independence Declaration (visited Feb. 9, 1996) <http://www.eff.org/barlow> ("Your legal concepts of propcrty, expression, 
much of the scholarly copyright discourse for almost two decades. This school analyzes the allocation of rights im creative works from a neoclassical market perspective. ${ }^{87}$ These scholars tout the efficiency of markets as the best means for resource distribution because they trust the market to optimize efficiency by placing a resource in the hands of the highest value user and directimg investment toward the most valuable uses. ${ }^{88}$ Accordingly, they support strong, centralized property rights. ${ }^{89}$ They see fair use as a very limited exception to the exclusive rights of copyright owners and the general system of transfers via the market, one that should be available only where the market fails to provide for a socially beneficial transfer. ${ }^{90}$ This view was perhaps most cogently articulated by Professor Wendy Gordon in her landmark article, Fair Use as Market Failure. ${ }^{91}$ Simce then, the market failure theory has been widely adopted and elaborated. ${ }^{92}$ As a result, courts have frequently overlooked noneconomic justifications for fair use.

\section{B. The Market Failure Theory Fails to Account for Many Valuable Uses}

The market failure theory of fair use works well in some situations. It explains cases in which a use is fair because a beneficial transfer might not occur in the open market, either because the copyright owner would not want to license the use or because the transaction costs would be prohibitive. This accounts for both de minimis problems and some holdouts. For

identity, movement, and context do not apply to us. They are based on matter, There [sic] is no matter here.").

87. This label, and much of the characterization, is borrowed from Netanel, supra note 18, at 308-24.

88. See Gordon, supra note 10, at 1605-14 (describing the application of the market model to copyright).

89. See, e.g., GoldsTern, supra note 10, at 178-79 ("The logic of property rights dictates their extension into every corner ... . To stop short of these ends would deprive producers of the signals of consumer preference that trigger and direct their investments."). This position follows from the standard Coasian premise that ownership of resources is necessary to encourage their efficient use. See generally Robert P. Merges, Of Property Rules, Coase, and Intellectual Property, 94 CoLUM. L. REv. 2655 (1994) for an explanation of why, contrary to standard Coase theorem analysis, neoclassical copyright scholars insist on imitial allocation of rights to copyright holders.

90. See, e.g., Gordon, supra note 10, at 1615 ("An economic justification for depriving a copyright owner of his market entitlement exists only when the possibility of consensual bargain has broken down in some way.").

91. Gordon, supra note 10.

92. A Westlaw search for Professor Gordon's name and the title of her article recalled 194 citations in law reviews and journals, the bulk of them in the last five years. The article has also been cited by the Supreme Court in Harper \& Row, Publishers, Inc. v. Nation Enterprises, 471 U.S. 539, 559 (1985) and Sony Corp. v. Universal City Studios, Inc., 464 U.S. 417, 478 (1984), as well as by several appellate courts. See Leibovitz v. Paramount Pictures Corp., 137 F.3d 109, 115 n.3 (2d Cir. 1998); Fisher v. Dees, 794 F.2d 432, 437 (9th Cir. 1986). Many other authors have subsequently echoed, elaborated or produced works that cover similar ground. See, e.g., 1 PAUL GoldsteIN, CopYright § 1.1 (2d ed. 1989); William M. Landes \& Richard A. Posner, An Economic Analysis of Copyright Law, 18 J. LEGAL STUd. 325 (1989). 
instance, where there is no ineans to pay for a use, the costs of obtaining permission inay well outweigh the benefit of the use to the user. Similarly, where the public benefit stemming from the use outweighs the owner's interest in being able to charge the price of her choice, a transfer will not occur unless fair use steps in. The market failure theory justifies a fair use finding for either of these uses.

However, the market failure theory is less useful in other contexts. Taken literally, the market failure theory implies that any use that can be paid for should be paid for. This is too broad. Even Professor Gordon recognized that the inarket model works only where both parties internalize costs and benefits-a use with large public benefit might fail if the user cannot internalize the benefits to defray the cost of the use..$^{93}$ Many authors influenced by Gordon appear to overlook this element of her analysis. ${ }^{94}$ The market failure theory, as used, typically only accounts for two types of failure, those due to transaction costs and those due to certain holdouts. ${ }^{95}$

Also, not all market failures produce fair uses. In general, owners have an absolute right to control certain uses of their work. ${ }^{96}$ Thus, $\dot{m}$ general, an owner can refuse uses of a work at any price. The market failure theory would have fair use come into play only where the owner's exercise of her rights would prevent a socially desirable transfer. But the point at which such a transfer is socially desirable, as opposed to merely desirable to the user, is ill-defined. The market failure theory provides hittle guidance as to what types of benefit to the public fair use should encourage or what criteria may be used to measure such benefit. Thus, the market failure theory has limited predictive value.

Nothing prevents many of the prototypical fair uses from being paid for. ${ }^{97}$ For example, an author or publisher could require a reviewer to

93. See Gordon, supra note 10, at 1607 (noting that one condition of a perfect market is that "all costs and benefits be 'internal' to the transactions"), 1630 ("When a defendant's works yield ... 'external benefits,' the market cannot be relied upon as a mechanism for facilitating socially desirable transactions.").

94. See, e.g. , Bell, supra note 10, at 599 ("[D]efeating the fair use defense requires only that an information provider guarantee that consumers can license copyrighted works at some price-not at any particular price."); $c f$. Netanel, supra note 18, at 310 ("[C]ourts and policymakers who have adopted the neoclassicist paradigm have generally overlooked the more nuanced, contextualized account that thoughtful scholars have sought to advance.").

95. See Loren, supra note 11 , at 6 . She observes

A permission system only remedies the market failure that occurs because of high transactions costs. A permission system does nothing to cure the kind of market failure that is more central to the purpose of fair use and the constitutional purpose of copyright: the market failure that occurs when there are significant external benefits associated with a Id. particular use that cannot be imternalized in any bargained-for exchange.

96. See 17 U.S.C. $\$ 106$ (1994).

97. See Weinreb, supra note 11, at 1300 ("Most of the uses mentioned in the statute as potential examples of fair use are ones in which a market likely would develop in the absence of fair use and in fact commonly does develop if fair use is denied."). But see Robert P. Merges, Are You Making Fun of 
license the quotation of a text in a book review. However, fair use has traditionally privileged such uses and should continue to do so. Suppose the owner wanted to occupy the criticism and parody market for the work; could the owner drive out all competition? Could the owner charge for uses in criticism or parody and choose to price licenses based on low favorable the use treats his work? Probably not, because society has an interest in free speech and the availability of objective criticism and unrestrained parody. This shows how fair use reflects policy objectives broader than the mere prevention of market failure; it implicates nonmarket values, as well. Market failure theory often neglects this aspect of fair use and, unfortunately, so do the courts that follow it.

Suppose, alternatively, that a copyright owner alleged that he miglit want to enter the market for parody or criticism but set license fees high enough that he could discourage competition. Here the owner does not even participate, but could claim the market and forestall any entry by others. Further, because the owner is willing to license this use of the work, there is no market failure. Nonetheless, use by a parodist or critic should be fair because granting the owner rights $m$ the market would foreclose public discourse.

All of these are examples im which market failure is not necessary to a finding of fair use. In fact, the Copyright Act makes no reference to market failure. Market failure is simply a model that was articulated relatively recently to explain certain decisions. The availability of the fair use defense im such imstances has often been explained by the market failure theory: courts conclude that because an owner is unlikely to license such use, the market will fail and therefore the use of the work should be found fair. However, this argument is backwards: such a use should be fair whether the market fails or not. That is, even if an author cured the market failure by offering the right to quote at a reasonable price, unpermitted, uncompensated use would still be fair because the right is not the owner's to exploit.

Denying the owner the right to exploit certain uses of a copyrighted work is consonant with the balance between owners and the public. Even if granting the author the right to control the market for criticism provided the author with a greater imcentive to create valuable works (both because she would be immune from criticism and because she could make money from it), it would decrease the value of resulting works to the public. The author's greater rights would interfere with the rights of others to criticize her works effectively, hainpering the marketplace of ideas. This is an extreme example, but it demonstrates that copyright should not give the

Me?: Notes on Market Failure and the Parody Defense in Copyright, 21 AIPLA Q.J. 305, 307 (1993) (arguing that the availability of the fair use defense to parodists should hinge in part on whether the parodist offered the owner a generous royalty prior to the release of the infringing parody). 
owner the right to exploit all collateral markets-there are some that should presumptively belong to him or her and some that should not. But how does a court determine $a$ priori which is which? The market failure theory resolves this paradox incorrectly by granting all rights in collateral markets to owners.

\section{Market Failure and New Permission Systems}

At the extreme fringe, some commentators argue that since new technological measures allow virtually any use to be momitored and compensated, perhaps fair use is no longer necessary..$^{98}$ The free market augmented by digital technology, these authors argue, will cure all market failures and make all uses compensable. ${ }^{99}$ Thus, they support charging users even for prototypical fair uses such as parody. ${ }^{100}$ This position is characterized by a rosy view of contract ${ }^{101}$ and technologies such as automated rights management. $^{102}$

While new methods of distribution may ease some transactions, these commentators seriously overstate the ability of technology to eliminate market failure and to ensure that a socially beneficial allocation of rights occurs. New systems may allow for a radical reduction in several kinc's of transaction costs, for example the cost to copyright owners of monitoring or preventing unauthorized use, or the costs to users of locating and securing permission. This would be closer to the perfect economic model of economists. On the other hand, neither party would have perfect information; they would still have to negotiate.

These commentators are rather vague as to how market failure will be eliminated. Electronic systenis may be well suited to "off-the-rack" uses, such as allowing a user to make a single copy of a recordimg. It is easy to standardize such prices based on factors such as deniand or the duration of

98. See, e.g., Bell, supra note 10, at 584 (positing a world governed by contract in which fair use may be reduced to a gap-filler).

99. See GoldSTEIN, supra note 10, at 224 ("[T]he celestial jukebox ... should substantially reduce the specter of transaction costs. As these costs dissolve, so, too, should the perceived need for safety valves such as fair use."); Merges, supra note 10, at 130 ("[B]ecause the contemporary fair use doctrine is predicated on a market failure rationale, and because an electronic exchange potentially eliminates this market failure for digital content, fair use law will significant [sic] shrink, or an alternative basis for fair use will be rediscovered."). For trenchant criticism of this perspective, see generally Cohen, supra note 11 (criticizing the adequacy of contract models for exchanges of intellectual property rights).

100. See, e.g., Bell, supra note 10, at 595 (arguing that "excusing non-payınent might encourage over-production of reuses that aim, for purely economic reasons, to offend copyright owners"). Professor Bell's argument seems to ignore the wealth of sources in the public doinain that are free to the user who is simply cheap.

101. See, e.g., Merges, supra note 10, at 118 ("Property rights will becoine irrelevant in the online environment because every transaction can and will be mediated by a contract.").

102. See Bell, supra note 10, at 567 ("ARM [Autoinated Rights Management] will radically improve the efficiency of licensing practices in the digital intermedia."). 
a performance. But what of more specialized uses, such as the right to make a film from a book or the right to integrate a photograph into a collage? What of uses that might be offensive to the author? How would an electronic permission system ease any but the most pedestrian consumer use $?^{103}$ In all other cases, the costs of negotiation are unlikely to be eliminated, regardless of the medium of exchange.

Proponents of "fared use" also fail to address how the concentration of copyright ownership affects the balance of power in negotiations. As numerous scholars have pointed out, creative properties are increasingly owned by a few major players. ${ }^{104}$ This consolidation of authority over rights may reduce competition and lead to coercion, particularly where the user is offered an adhesion contract. Often, contracts supersede copyright. Witness, for example, the frequent use of the shrink-wrap license to protect material that is unprotectible by copyright. ${ }^{105}$ Contract law will not adequately effectuate the distributive function of copyright. Nor, as the next Part argues, do courts.

\section{IV}

The Current Analysis Does Not Adequately Distinguish between Those Uses That Should Be PaId for and Those That Should Not

This Part examines how market failure theory regards uses of copyrighted works im new markets. It shows how the bright-line assumption that market failure theory makes about ownership prevents any meaningful fair use inquiry into new markets by courts. It then describes how strategic behavior by users of copyrighted works further warps evidence of new markets, making it difficult if not impossible to disprove the existence of a market for a new use.

\section{A. Market Failure Analysis of New Markets Is Too Simplistic}

Market failure theory does not adequately distinguish between uses that should be paid for and those that should not. This problein steins from the bright-line assumption market failure theory makes about copyright and allocative efficiency: that every market presumptively belongs to the

103. Professor Merges argues that this problem could be solved where market rates are set by experts in the trade and that their valuations would be both more accurate and less subject to lock-in than those in a compulsory license setting. See generally Robert P. Merges, Contracting into Liability Rules: Intellectual Property Rights and Collective Rights Organizations, 84 CALIF. L. REv. 1293 (1996).

104. See, e.g., Benkler, supra note 49 , at $400-08$.

105. This phenomenon has been discussed ad nauseum in law reviews. See, e.g., Symposium, Intellectual Property and Contract Law for the Information Age: The Impact of Article $2 B$ of the Uniform Commercial Code on the Future of Information and Commerce, 87 CALIF. L. REv. 1 (1999). The leading case in the area of shrink-wrap hicenses, ProCD, Inc. v. Zeidenberg, 86 F.3d 1447 (7th Cir. 1996), concerned some of the same data held unprotectible by copyright in Feist Publications $v$. Rural Tel. Serv., 499 U.S. 340 (1991). 
owner. ${ }^{106}$ Where no market failure exists, they see no reason to allow a fair use. ${ }^{107}$

Market failure theorists shore up their analysis by claiming that fair use prevents the proper formation of new markets. As Professor Gordon has written:

This inquiry should also include harm that has not yet occurred but is likely to occur. Both the loss of revenues anticipated under the market structure prevailing at the time of suit, and the loss of revenues that would be generated under whatever market structure would follow upon a grant of infringenent, should be relevant .... To award fair use without regard to the possibility of imminent change in the market structure might be to make permanent an otherwise curable market failure and thus potentially to insulate a new and valuable use from the stimulus of consumer demand. ${ }^{108}$

Again, this begs the question. Asking what "market structure would follow upon a grant of infringement" assumes that the owner should be able to exploit a market if one exists. Furthermore, it assumes that a market will form. ${ }^{109}$ If the infringing use is not unique, there will always be subsequent uses of the saine type; if such use has been found to be within the bounds of copyright by courts, parties will take care to obtain licenses and there will be a market. This formulation excludes only unique uses, those unlikely to be repeated.

Professor Merges has lauded the American Society of Composers, Authors, and Publishers (ASCAP) as a model for market clearance mechanisms. ${ }^{110} \mathrm{He}$ documents how ASCAP overcaine obstacles to create a workable licensing mechanism for public performance rights of musical compositions and suggests that ASCAP's model can be translated into other areas of copyright management. ${ }^{111}$ However, his argument does not adequately address the special framework in which ASCAP operates, that of the coinpulsory license. A system like ASCAP functions precisely because Congress has both decided that a use does not require the owner's permission and assigned a price to such use a priori. ${ }^{112}$ Absent such determinations, a licensing system works only where each copyright owner

106. See supra note 89.

107. See supra note 90 and accompanying text.

108. Gordon, supra note 10 , at 1620 (internal citations omitted).

109. See, e.g., Merges, supra note 10, at 135 ("Rather than focusing on whether a market might form for the copyrighted work, we should assume it will. The only relevant questions are: (1) which class(es) of users should be allowed to bypass the presumptive market; and (2) how much revenue should the copyright holder be forced to forego to serve the goals of fair use?").

110. See Merges, supra note 103, at 1378 ("ASCAP's experience shows that it is possible to apply existing institutional know-how to a new set of transactional problems.”).

111. See id. at 1328-40.

112. See supra note 16 . 
consents in advance to a pricing schedule and agrees to delegate the power to authorize use.

Furthermore, the impediments to such clearance solutions are substantial. No one would choose to use a clearance system unless it covered a substantial inventory of works and offered a licensee reasonable assurance of freedom from further liability. ${ }^{113}$ Even if the clearance mechanisin dealt with a specialized market, it would still have to obtain the cooperation of a significant portion of the copyright owners in the field. It might take a substantial period of time for the service to gain acceptance, and in the interim the service would be of limited utility. Should a user have to pay while waiting for licensors to iron out the problems in a systein?

Clearance systems can also impinge on the privacy and free speech interests of users. As Professor Cohen has pointed out, consuinptive uses can also implicate First Amendment rights, particularly where copyright manageinent systems require momitoring of individual reading habits. ${ }^{114}$ Monitoring can also have other side effects. For instance, records of which articles a company was photocopying might be used by the coinpany's coinpetitors to discover what research the company was conducting. ${ }^{115} \mathrm{~A}$ coinpetitor could use this information to deduce valuable trade secrets.

Clearly, permission systems provide a questionable solution at best. However, market failure theorists would have any fair use determination turn on the inere existence of a licensing mechanism because they assume ex ante that all uses of a copyrighted work belong to the author. If the rights of authors are assunied, fair use bypasses any meaningful analysis of

113. Professor Goldstein's discussion of the early years of ASCAP illustrates this point nicely:

The appeal of a blanket license would necessarily turn on the comprehensiveness of the ASCAP repertory; no licensee wanted to be put to the bother of determining whether a song it chose to play was in ASCAP's repertory, nor did it want to run the risk of guessing wrong and facing an infringement lawsuit froin an unaffiliated composer or publisher.

GolDSTEIN, supra note 10 , at 71 .

114. See Julie E. Cohen, A Right to Read Anonymously: A Closer Look at "Copyright Management" in Cyberspace, 28 CoNN. L. REv. 981, 1003-04 (1996) (noting that "[u]ntil recently ... the technological means to monitor individuals' reading habits did not exist" and noting the "close interdependence between receipt and expression of information and between reading and freedom of thought"). Although Cohen makes this point with regard to electronic monitoring, the same point can also be made regarding any hicensing system which requires tracking of specific uses. One form of license offered by the CCC requires users to report actual use. See Crews, supra note 54, at 304 (describing CCC's Transactional Reporting Service).

115. As Judge Leval noted in the Texaco district court opinion with regard to CCC's Transactional Reporting Service:

Users ... objected to identifying the articles they copied because they feared this could give information to their competition as to where their research efforts were being concentrated. Accordingly, CCC eliminated the need to identify the item copied. Since January 1, 1983, the information provided to $\mathrm{CCC}$ has been reduced to the journal's standard International Standard Serial Number ("ISSN"), publication year, and the photocopy permissions fee set by the publisher (multiphed by the number of copies made).

American Geophysical Union v. Texaco Inc., 802 F. Supp. 1, 7-8 (S.D.N.Y. 1992). Although such efforts may be helpful in masking which articles a company copied, a competitor might still be able to infer this information through careful study of these records. 
the propriety of a market. Market effect analysis degenerates from an inquiry into whether a use "should" be paid for to whether a use "can" be paid for. Furthermore, as argued below, the presence of a inarket for a use does not necessarily indicate that a use is within the scope of the author's rights. ${ }^{116}$ The next section addresses how strategic behavior on the part of users makes "can" too easy a standard.

\section{B. Strategic Behavior Warps Fair Use Analysis}

Courts that examine licensing evidence often do not recognize how market practices are shaped by strategic behavior. ${ }^{117}$ Fear of liability causes users to obtain licenses for borderline uses rather than risk the cost of a lawsuit. This licensing can, in turn, create a narket that can be held against subsequent users to disprove the fairness of a use.

Copyright is not self-enforcing: copyright owners must act to guarantee their exclusive rights. Presunably each party calculates its chances of success and the anticipated settlement value of a claim. Where a use is clearly an infringement, an owner will likely choose to shake down or sue a user. Where a use is at best an attenuated infringement, the owner may be unlikely to sue, but may still threaten to do so. Even where a claim is groundless, an owner can send a "cease and desist" letter almost without cost. Licensing takes place in the shadow of a plaintiff-friendly courtroom.

Soine users, particularly repeat players or deep pockets, are likely to acquiesce to a new market. This is particularly true in the case of media congloinerates that are large copyright owners themselves. These parties are probably indifferent to the cost of licensing: when they must pay to license a new use of a copyrighted work they can be secure in the knowledge that they can license their own properties to others. There is no net harm. For the consumer or the creator without an inventory of valuable works, this result is nore troubling. Not only may she be held accountable for another user's caution, but there is also no corresponding benefit to her from a custom of payment. ${ }^{118}$

A user of copyrighted inaterial is likely to pay for borderline uses for several reasons. First, it may be cheaper to license a use than to litigate a copyright infringenent suit. Even where litigation is brought only for nuisance value, a user may have to expend substantial time and money defending the suit. Second, a user may be vulnerable to the threat of

116. See infra Part IV.B.

117. Numerous scholars have applied the lessons of economic theory to understand bargaining for intellectual property rights. See, e.g., Cohen, supra note 11, at 515-59; Lemley, supra note 22, at 105859; see generally Robert P. Merges, Intellectual Property Rights and Bargaining Breakdown: The Case of Blocking Patents, 62 TENN. L. REv. 75 (1994). Generally, their analyses focus on modeling market behavior to generate optimal rules regarding entitlements rather than on describing market behavior itself.

118. For an example illustrating this phenomenon, see infra note 128. 
injunctive relief. This is particularly true in the entertainment industry, which is often geared to marketing fads and time-sensitive release dates. ${ }^{119}$ Third, the user may fear the reputational effects of being labeled a copyright infringer. These might color the user's dealings with other owners or third parties. Thus, copyright owners can extract license payments by threat of litigation. Even without an explicit threat, copyright users may be compelled to license noninfringing uses prophylactically.

If users know that a custom of paid use will be held against them in court, it may encourage them to behave in inefficient ways-to license prophylactically or not to license at all. This scenario resembles the prisoner's dilemma: if no one licenses a given type of use, none are liable because there is no market, absent a judicial or legislative determination to the contrary. However, where one user licenses a type of use, all other users are more likely to be held liable because the copyright owner can demonstrate a market for the use. ${ }^{120}$ The party that foregoes a license may later be held liable due to the behavior of her more cautious counterpart.

Perhaps the paradigmatic example of this phenomenon is digital sampling. Although digital samples are ubiquitous im popular music, the legal rules regarding sampling are ill-defined. No case has seriously addressed the extent to which sampling of copyrighted music may be fair use. ${ }^{121}$ The leading case $\mathrm{e}^{122}$ on infringement of copyright in musical works by sampling, Grand Upright Music Ltd. v. Warner Bros. Records, Inc. , ${ }^{123}$ never progressed beyond the preliminary injunction phase. Furthermore, because

119. For example, the producers of the film Devil's Advocate faced an infringement case for the inclusion of a mural based on a copyrighted bas-relief sculpture. Fearful of delaymg the film's release on videocassette, the producers settled. Under the terms of the settlement, they re-cut the film, digitally altering the background that liad infringed the plaintiff's artwork. See Francis X. Clines, Creator of Religious Art Prevails on 'Devil' Film, N.Y. TIMEs, Feb. 14, 1998, at A6.

120. One judge expressed antagonism to the expansion by publishers as follows:

Simply because the publishers have managed to make licensing fees a significant source of income from copyshops and other users of their works does not make the income from the licensing a factor on which we must rely in our analysis. If the publishers have no right to the fee in many of the instances in which they are collecting it, we should not validate that practice by now using the imcome derived from it to justify further imposition of fees.

Princeton Univ. Press v. Michigan Doc. Serv., Inc., 99 F.3d 1381, 1397 (6th Cir. 1996) (en banc) (Merritt, J., dissenting), cert. denied, 520 U.S. 1156 (1997).

121. This is not to say the issue has not received substantial attention in print. Throughout the past decade the legality of digital sampling and its implications has been perhaps the student author's favorite dead horse. Two of the better examples are Carl A. Falstrom, Note, Thou Shalt Not Steal: Grand Upright Music Ltd. v. Warner Bros. Records, Inc. and the Future of Digital Sound Sampling in Popular Music, 45 Hastings L.J. 359 (1994), and Michael L. Baroni, Note, A Pirate's Palette: The Dilemmas of Digital Sound Sampling and a Proposed Compulsory License Solution, 11 U. MiAMI ENT. \& SPORTS L. REv, 65 (1993).

122. The only other sampling case that has received any attention is Jarvis v. A \& M Records, 827 F.Snpp. 282 (D.N.J. 1993). Although that case laid out the legal issues pertaining to samplimg (particularly an analysis of substantial similarity) in much greater depth than did Grand Upright, its precedential value is limited. The court merely found a triable issue of fact on whether use of plaintiff's recording was an infringeinent. After the ruling, the parties apparently settled.

123. 780 F. Supp. 182 (S.D.N.Y. 1991). 
plaintiffs had apparently conceded both copying and substantial similarity ${ }^{124}$ the opinion did not even discuss which of the copyright holder's exclusive rights were infringed by the use of the sample or how such rights may have been infringed. Nonetheless the judge produced a broadlyworded opinion that equated sampling with theft. ${ }^{125}$ This drove many in the music industry to believe that sampling is per se infringement of copyright in a composition and sound recording. ${ }^{126}$ As a result very few cases have been reported. Most of those that are concern the validity of the plaintiff's copyright in the sound recording, which is a fundamental element of a copyright claim. ${ }^{127}$ The paucity of reported cases and their emphasis on fundamental failures of proof implies that defendants in sampling cases go to trial only when confronted with meritless claims. ${ }^{128}$

Anecdotal evidence suggests that, rather than face infringement suits, record compamies prefer to license the use of any questionable sample prophylactically. ${ }^{129}$ Because neither statute nor case law has set any clear standards regarding how much (either qualitatively or quantitatively) is an infringement, users are driven to license even samples that might not infringe or inight qualify as fair use under a full analysis. ${ }^{130}$ In other words,

124. See Robert G. Sugarman \& Joseph P. Salvo, Sampling Litigation in the Limelight, N.Y.L.J., Mar. 16, 1992, at 4, 5, 7 n.4.

125. The opinion began, "'Thou shalt not steal." Grand Upright, 780 F. Supp. at 183. Judge Duffy also took the extreinely unusual measure of referring the matter to the U.S. Attorney for prosecution. See id. at 185.

126. In a thoughtful commentary, the plaintiff's attorney subsequently characterized the industry's reaction as follows:

For those engaged in sample licensing, there had previously been no clear-cut legal guidelines. No one could say for certain whether the use of a small piece of someone else's recording or song required a hicense. Perhaps it came under some exclusion in the copyright law? Perhaps it was protected by 'freedom of speech' or was otherwise excluded? Many in the trade now think that the O'Sullivan case closed the door on all these questions.

Michael F. Sukin, Rappers Shouldn't Bash Victor in Sampling Suit: O'Sullivan Was Only Defending His Rights, BILlBOARD, June 6, 1992, at 6.

127. See, e.g., Tuff 'n' Rumble Mgmt. Inc. v. Profile Records Inc., 42 U.S.P.Q.2d 1398 (S.D.N.Y. 1997) (granting summary judgment in sampling case where plaintiff could not demonstrate ownership of copyright in sound recording); Fantasy Inc. v. La Face Records, 43 U.S.P.Q.2d 1700 (N.D. Cal. 1997) (granting summary judgment and denying application for leave to file motion for reconsideration where plaintiff could not demonstrate ownership of copyright in sound recording).

128. See Julie Taraska, Sampling Remains Prevalent Despite Legal Uncertainties, BILLBOARD, Nov. 14, 1998, at 12, 14 ("[L]abels avoid going to court ... it's cheaper, even if the claims paid off are bogus.").

129. See generally id. (describing music industry sample clearance practices). This behavior is consistent with the theory that repeat players and deep pockets are likely to acquiesce to payment for new uses. The record industry is dominated by five major labels, each of which is very wealthy and owns the rights to tens of thousands of recordings. Because the size of the major labels makes them attractive targets for infringement suits, they are likely to err on the side of caution in obtaining hicenses for uses of copyrighted works. On the other hand, there is a corresponding benefit to each label in that it has an inventory of works that it can license to others.

130. Plenty of misinformation circulates. See, e.g., id. (opining that "[b]y law, if a song is not in the public domain an artist must pay to sample it"). Clearly, this is wrong. Assuming an artist took 
an industry custom has arisen whereby users pay for licenses even where they do not need thein. Thus, if any user ever were to challenge the permissibility of sampling, there would be clear evidence of a market for sample licenses. Strategic behavior by users has not only prevented the creation of fair standards, it has entrenched unfair ones.

This problem of strategic behavior and custom is perhaps most troubling in the context of incidental uses of copyrighted material. Since copyright infringement does not rely on a finding of intent, a party may be liable although he was unaware of both the use and the need to license it. One can envision all sorts of traps for the unwary, for example an enterprising artist wallpapering a locale with her copyrighted work in hopes that it would be reproduced by film or television cameras. ${ }^{131}$

If copyright always has a penumbra, and users always license just outside it, copyright will continually expand in scope. As each use becoines legitimized by imdustry acquiescence to custom or judicial determination, the next one becomes the border. In this case, the rationale for licensing is not so much a circle as a spiral in which all rights devolve to the owner. This result is troubling because it enables copyright owners to reap inore than they should, which throws off the constitutional balance between authors and users. Allowing the copyright owner too broad a right discourages valuable uses. The inarket failure theory, coinbined with overly credulous judicial interpretation of licensing evidence, leaves courts unable to assess rights adequately in new markets.

\section{$\mathrm{V}$ \\ Proposals to Reform Market ANALYSIS}

At bottom, the question in fair use analysis of market harm is which markets we should allow authors to control and exploit. Should the author be allowed to fence off any territory she identifies? For the reasons outlined in Part IV above, the answer should be no. However, this leaves the difficult problem of formulating an alternative standard. An ideal standard should balance the interests of creators, users, and the public.

It is unwise for courts to allow owners the right to exploit a market without first considering the effects of this right both on creators and users of copyrighted works. A court inight ask questions such as the

copyrightable expression from another song, a court would still have to find substantial similarity between the two recordings to support a claim of infringeinent.

131. A nodest version of this scenario was litigated several years ago when a crew filming on location photographed a building and its sculpted courtyard. The courtyard then appeared in the film and advertising for the film Batman Forever. The producers had obtained permission to film from the owner of the building, but not from the artist himself. The court found no infringement of the copyrighted courtyard, concluding that the portions of the sculpture included in the filin were part of the building, and thus any claim was prevented by 17 U.S.C. $\S 120$ (a). See Leicester v. Warner Brothers, 47 U.S.P.Q.2d 1501, 1508-09 (C.D. Cal. 1998). 
following: Will a market grant lead to more production of valuable works? Will it create a windfall to authors? Will it defeat the expectations of the public? Will it allow the public to enjoy copyrighted works? Will it interfere with the public discourse? Will it interfere with privacy interests? Will the societal costs of admimistration of licenses outweigh the benefits to the author? Recognizing the incremental nature of creative enterprises, will it promote the progress of the useful arts? This Part offers a number of suggestions for reforming market effect analysis and the award of new markets to better achieve this balance.

\section{A. Breathing Space}

At a minimun, fair use should guarantee that copyright does not interfere with a robust public discourse. As the Supreme Court observed in Campbell, fair use serves to "guarantee ... breathing space within the confines of copyright." 132 To achieve this goal, fair use should be available in cases beyond simple market failure: the fair use defense must also be available for uses that implicate the defendant's right to comment upon an owner's work. ${ }^{133}$ Additionally, it may be desirable to preserve some leakage $\mathrm{m}$ the market to ensure that the "Progress of Science" is not stifled where the works of a later author implicate those of the former in minor ways. Furthermore, since even consumptive uses may implicate rights in free expression, courts should approach the extension of rights cautiously. ${ }^{134}$ This proposal does not represent a departure from established fair use jurisprudence, but it merely affirms a traditional function of copyright. However, given the trend im copyright analysis, this view is increasingly rare.

\section{B. A Reasonableness Standard}

As the name implies, fair use has often reflected popular norms and expectations of which uses are reasonable or custoinary. ${ }^{135}$ To an extent, this is apparent in the Supreme Court's holding in Sony Corp. v. Universal Studios, Inc. that the use of the VCR by consumers to "time-shift" television programs was fair use. ${ }^{136}$ This is what Professor Jane Ginsburg has characterized as "the true holding of Sony: there are millions of VCRs in daily use in American households; the Supreine Court cannot hold that

132. Campbell v. Acuff-Rose Music Inc., 510 U.S. 569, 579 (1994).

133. As discussed in Part III.C, supra, certain proponents of the market failure theory and new permission systems would have even these uses paid for.

134. See supra note 114 and accompanying text.

135. See generally Lloyd L. Weinreb, Fair's Fair: A Comment on the Fair Use Doctrine, 103 HARV. L. REV. 1137, 1161 (1990) ("The reference to fairness in the doctrine of fair use imparts to the copyright scheme a bounded normative element that is desirable in itself. It gives effect to the community's established practices and understandings.").

136. See Sony Corp. v. Universal Studios, Inc., 464 U.S. 417, 454-55 (1984). 
millions of Americans are committing copyright infringement every day." ${ }^{137}$ Copyright law is shaped by public perception and courts should not criminalize behaviors in the normal realm of consumer expectation. People are unlikely to follow rules that criminalize those behaviors. ${ }^{138}$ Furthermore, where a case concerns a private, noncommercial activity taking place in the home, as Sony did, a law against the use either requires invasive momitoring or mvites the public to disregard the law. To make laws that are unenforceable undermines the legitimacy of copyright.

Where customs of uncompensated use have arisen, courts should not remove uses from the public domain without careful consideration of the consequences both to users and to copyright law itself. To do so threatens personal freedoms and the legitimacy of copyright law. Instead, courts should consider whether a custom of use is ingrained and what this norm reflects in society. Unfortunately, this standard presents a line-drawing problem, just as the current one does. ${ }^{139}$ An explicit recognition of the public interest in reasonable, predictable laws might guide courts a little better, but they would still be faced with a policy-making function.

\section{Incentive Analysis}

A court assessing a new market might also analyze the market in terms of the constitutional balance between the rights of the public and incentives to authors. The court could, in effect, ask, "Is granting this inarket to authors likely to encourage the production of works?" or, conversely, "Will denying authors the right to exploit this market dimimish their incentives to create works?" As discussed above, ${ }^{140}$ granting authors of preexisting works rights in new uses inay depart unnecessarily from copyright's incentive structure. For instance, if I publish a successful science fiction book, I can currently exploit the book in a host of ways: a book-on-tape version, a film, T-shirts, action figures, and so forth. My copyright in the book will extend for a minimum of seventy years. ${ }^{141}$ Is it necessary to grant me and my assigns rights to exploit not only every medium currently existing but also every medium of expression discovered im the next seventy years? Is the prospect of returns to my heirs that are

137. Ginsburg, supra note 10 , at 18 (paraphrasing Professor Alan Latman) (internal citation omitted).

138. See, e.g., Jessica Litman, Copyright Noncompliance (or Why We Can't "Just Say Yes" to Licensing), 29 N.Y.U. J. INT'L. L. \& PoL. 237, 239 (1997) (analogizing overly broad copyright laws to the fifty-five mile per lour speed limit: "People don't obey laws that they don't believe in.").

139. For instance, both the majority and dissent in American Geophysical Union v. Texaco Inc., 60 F.3d 913 (2d Cir. 1994), claimed to recognize only "traditional, reasonable, or likely to be developed markets," id. at 930 (majority), but they disagreed radically as to what markets were traditional, reasonable or likely to be developed. See id. at 936 (dissent).

140. See supra note 50 and accompanying text.

141. See 17 U.S.C. $\$ 302$ (1994) (granting copyright holders protection for the term of the author's life plus seventy years or, in the case of joint works and works for hire, longer). 
distant, highly speculative, and deeply discounted for the time value of money likely to make me write more or better? The new rights may function as a wimdfall, an extra right beyond those that the author expected or needed to create the work.

For authors who create works after the development of new uses, the question remains whether giving the particular market to an author is necessary to stir production. The right to exploit traditional markets for the work may be an adequate incentive. All of the currently-existing markets discussed above provide rich coinpensation to a successful author. An inquiry into incentives might help guarantee that the expansion of the author's right does not disrupt copyright's balance between authors and users.

\section{Shift the Burden of Proof of Market Effect}

Fair use analysis might also be made inore equitable by shifting the burden of proof to the plaintiff on the market effect factor. As observed above, ${ }^{142}$ the fair use statute requires a user of copyrighted works to prove that there is no market for a particular use of a work. This presents several problems. First, it nay be virtually impossible for a user to produce evidence that there is no market for the infringing use: what evidence can a user produce beyond a bald assertion? Second, the owner is better suited to produce evidence about the existence of a inarket-the facts inay be particularly within the control of the owner. Even so, evidence that some users currently pay for a use of a copyrighted work nnay be of dubious inport, for the reasons outlined in Part IV.B above. However, shifting the burden of proof on this factor might stir courts to conduct a inore searching inquiry into the validity of licensing evidence. A court might ask, for exainple, if the licenses cited represent consideration to the owner for a valuable use or merely protection against liability. Thus, shifting the burden of proof would allow for a fairer and inore coinplete analysis of market effect evidence.

Although the overwhelming weight of authority suggests that fair use is an affirmative defense, ${ }^{143}$ the statute does not mandate that the burden of proof be placed on the defendant. It only stipulates four types of evidence that inust be considered, not who must produce the evidence. ${ }^{144}$ Nonetheless, given that Supreme Court jurisprudence and legislative history both state that the burden of proof is on the infringer, it would probably require a legislative amendinent to the statute to effect this change. However,

142. See supra notes 57-59 and accompanying text.

143. See, e.g., Campbell v. Acuff-Rose Music, Inc., 510 U.S. 569, 590 (1994); Harper \& Row, Pubs., Inc. v. Nation Enters., 471 U.S. 539, 561 (1985); H.R. ReP. No. 102-836, at 3 n.3 (1992).

144. See 17 U.S.C. $\$ 107$ (1994) ("In determining whether the use made of a work in any particular case is a fair use the factors to be considered shall include ...."). 
doing so would make each fair use determination better founded and more just.

\section{E. A Trial Period of Exploitation}

Alternatively, we might allow a copyright owner a modest period to develop a workable market for the exploitation of her work. Professor Merges has advocated enforcmg the rights of owners in the short term. ${ }^{145}$ Under such a system, the author would then have the burden of showing that the value of the market outweighs the transaction costs associated with it. A naked grant to the author of the rights ex ante may give the owner little incentive to exploit the market. She may not do so unless she anticipates large returns or a threat of forfeiture for failing to manage the resource properly.

This proposal would be impossible without a legislative enactment and even so might be unworkable. Courts do not have the power to issue temporary grants, nor do they have resources to momitor the development of markets. The Copyright Office might be capable of administering such a system, although its role in copyright administration has been drastically scaled back in recent years. ${ }^{146}$ Furthermore, it would be difficult to determine when a trial grant shonld begin or end: should the rights run from the development of a new technology, from the first commercial use of the technology in a new medium, or from some other date? Lastly, the administrative body would have to formulate standards to determine whether the copyright owner had managed the copyright use effectively. Clearly, this proposal is somewhat fantastic. Nonetheless, from a normative perspective, it represents a mice compromise by allowing the owner the right of exploitation but forcing her to do so effectively.

\section{F. Leave the Award of New Markets to Congress}

Lastly, one might ask whether the courts should determine who gets rights to new uses at all. The Copyright Act provides little guidance in determining the scope of the owner's monopoly. In general, courts have deferred to Congress before extending copyright to new media. ${ }^{147}$

145. See Merges, supra note 10, at 131 ("[W]hy not fully enforce the rights and see whether the market follows? ... If, after some reasonable period of time, no potential market takes shape, then perhaps fair use is in order.").

146. The Berne Convention Implementation Act of 1988, Pub. L. No. 100-568, 102 Stat. 2853 (1988), eliminated registration with the Copyright Office as a condition of copyright protection, although it is still advantageous to copyright owners to do so. See 17 U.S.C. $\$ 408$ (a).

147. See, e.g., Sony Corp. v. Universal City Studios, Inc., 464 U.S. 417, 431 (1984) ("The judiciary's reluctance to expand the protections afforded by the copyright without explicit legislative guidance is a recurring theme."). A string of opmions authored by Justice Holmes almost a century ago represents the only major exception to this theme in the Court's jurisprudence. See GoldsrenN, supra note 10 , at 33 . 
This deference makes sense because Congress is better suited to making broad policy determinations than are the courts. Congress can conduct hearings to support broad findings of fact that ensure a determination represents a wide class of interests. By contrast, a rule made under the limited factual circumstances of a case may make little sense in another situation. Where new markets are concerned, courts may be unable to form sufficiently far-sighted rules. One might well question the wisdom of allowing courts to foreclose markets ex ante. For example, Sony allowed the plaintiffs to develop a collateral market for home video that is more lucrative than the origimal market. ${ }^{148}$ Ironically, this market may well have been crippled if the Sony plaintiffs had prevailed because the plaintiffs sought injunctive relief. Granting an injunction would have not only frustrated public enjoyinent of a new technology, it would have impeded the growth of a valuable market for copyright owners.

Furthermore, Congress can tailor solutions to balancing problems far more narrowly than the courts can. For instance, the Audio Home Recording Act (AHRA) ${ }^{149}$ illustrates Congress's ability to craft innovative solutions to complex problems in new markets. ${ }^{150}$ The AHRA resolved a battle over digital audiotape (DAT) technology between owners of copyrights in sound recordings and manufacturers of DAT equipment. Copyright owners sought to exclude DAT machines froni the American market, arguing that the DAT would be used by consumers to produce near perfect copies of recorded works and thus cause substantial harm through lost sales. Neither copyright owners nor manufacturers had suggested any clearance system that was not invasive or expensive. The statutory coinpromise protected the rights of copyright owners by requiring DAT machines to contain serial copy management systeins that prevented copying from copies and by imposing a royalty on both DAT machines and blank DAT cassettes for distribution to performers, publishers and record coinpanies. To effect a fair distribution of royalties, the AHRA established a system to collect and distribute royalties and to resolve disputes over payments. This compromise represented a novel solution to a situation that required a difficult balancing of interests. ${ }^{151}$ It smultaneously guaranteed authors compensation for the use of their works in a new medium and guaranteed the expectations of consumers in the use of technology and

148. By 1994, profits from home video accounted for almost three times the profit of United States box office sales. See Alan Deutschman, Scramble on the Information Highway, ForTuNE, Feb. 7, 1994, at 129, 131.

149. Pub. L. No. 102-563, § 2, 106 Stat. 4237,4240 (codified as 17 U.S.C. $\$ \S 1003$ to 1007 (1994)).

150. See id.

151. For an argument critical of the AHRA and the legislative process that created it, see Lewis Kurlantzick \& Jacqueline E. Pennino, The Audio Home Recording Act of 1992 and the Formation of Copyright Policy, 45 J. CopYrIGHT Soc'Y U.S.A. 497 (1998). 
personal privacy. What is more, a court could not have resolved the conflict in this manner because courts do not have similar latitude in fashioning remedies like compulsory licenses or royalties. Courts are limited to ordering damages and injunctions. Thus, Congress is better situated to resolve the complex needs of multiple parties raised by new technologies.

More importantly, courts may exceed their power under the Constitution when they grant authors rights in nontraditional markets. The Constitution grants the power "to promote the Progress of Science and useful Arts, by securing for limited Times to Authors and Inventors the exclusive Right to their respective Writings and Discoveries"152 to Congress, not to the courts. In part, the question of whether the grant to a copyright owner of a right to exploit a nontraditional market is a new right is defimitional-those im favor of protection for new uses might characterize those uses as part of the existing scope of copyright, rather than as a grant of a new market. ${ }^{153}$ Thus the right to control use of a work in a new medium imight be seen as a species of the right of reproduction in "copies or phonorecords," 154 a broad category under the Copyright Act. ${ }^{155}$ On the other hand, the right to exploit a use that did not exist before is clearly a "new" right in some senses.

Detractors might argue that allowing courts authority over the scope of copyright protection is more efficient. Society is spared the expense of hearings if Congress can operate in broad strokes and not have to determine rights in each new technology or new use of existing technology. Furthermore, a judicial remedy shifts the burden of establishing copyright protection to the party who desires it. On the other hand, since defendants have been unwilling or unable to defend these suits, the courts may never get a chance to adjudicate these questions properly. As a result, the constitutionally mandated copyright balance may be skewed.

Some argue that Congress is unable to respond adequately to new technologies. Congress's handling of photocopying lends support to this position. ${ }^{156}$ Furthermore, Congress acts slowly. ${ }^{157}$ Others question the

152. U.S. CoNST. art. I, § 8, cl. 8 .

153. See supra note 70 and accompanying text.

154. 17 U.S.C. $\$ 106(1)$ (1994).

155. "Copies" are defined as "material objects, other than phonorecords, in which a work is fixed by any method now known or later developed." 17 U.S.C. \$ 101 (1994).

156. Although the photocopier was introduced in 1960, Congress did not take action until 1976 (after having delayed until Williams \& Wilkins Co. v. United States, 420 U.S. 376 (1974), was decided). The Copyright Act of 1976 failed to clarify the field. Rather than create a bright line rule, Congress in effect created several vague ones. The relationship between photocopying under the fair use statute, 17 U.S.C. $\$ 107$, and the exemptions of 17 U.S.C. $\$ 108$ has been a source of persistent confusion. See Regent's Guide to Understanding Copyright and Educational Fair Use, 5 J. INTELL. Prop. L. 243 (1997), for a valiant attempt to explain the legal standards that pertain to educational photocopying. 
ability of Congress to expand copyright protection against entrenched patterns of consumer use. Passing a law that criminalizes a use that is widespread may be politically unpalatable. ${ }^{158}$ However, the converse is also true-once rights are granted to copyright owners, it is difficult to withdraw them. ${ }^{159}$ Furthermore, the passage of the Sonny Bono Copyright Term Extension Act has demonstrated the ability of Congress to expand substantially copyright protection without much public response. ${ }^{160}$ One might even argue that Congress is too friendly with the copyright imdustry to administer policy fairly. ${ }^{161}$ On the other hand, the sheer administrative difficulty of expanding copyright protection to each new use might act as a brake on unwarranted expansion of owner rights. In any event, Congress has shown the ability to make difficult decisions regarding the scope of copyright, and it has both the resources and the constitutional authority to resolve questions about the scope of copyright protection more effectively than courts can.

\section{CONCLUSION}

When courts are confronted with fair use claims regarding a nontraditional use for a copyrighted work, they are faced with difficult decisions regarding the scope of the copyright monopoly. The market effect inquiry as applied to new markets is too difficult for courts to undertake without a clear understanding of which objectives they should serve. They risk upsetting the constitutional balance of copyright by giving the author either

157. As Professor Goldstein points out, copyright owners suffer and consumer electronics companies benefit any time Congress postpones a decision on home copying. See GoldsTEIN, supra note 10, at 134:

As time passes, more and more consumers acquire new copying equipment and, with it, the expectation of free copying. As habits of free use proliferate, the prospects for dislodging them diminish. Ideal, balanced laws that might have becn possible within a year or two of a new technology's arrival in the marketplace can, five years later, be politically impossible. Id. Or as he says in his elegant epigram, "[Rlights delayed are usually rights demied." Id. at 202.

158. See id. at 33 ("Observing what he called the 'iron law of consensus,' a former staff member of a Senate copyright subcommittee has cautioned not to look to Congress for help if any proposed imposition of copyright liability disrupts entrenched consumer habits.").

159. A rare example of this type of action is Feist Publications v. Rural Tele. Serv., 499 U.S. 340 (1991) (reversing settled law that white pages were copyrightable because the Court found the organization and selection insufficiently original). It is further worth noting that data owners have attempted to avoid or supersede this both by contract, see ProCD, Inc. v. Zeidenberg, 86 F.3d 1447 (7th Cir. 1996), and by calls for legislative database protection.

160. See Sonny Bono Copyright Term Extension Act, Pub. L. No. 105-298, § 101, 112 Stat. 2827 (codified im scattered sections of 17 U.S.C.). But see the Copyright's Cominons website for an cxample of the academic response to the SBCTEA. Copyright's Commons (last modified Nov. 17, 1999) $<$ http://cyber.law.harvard.edu/cc/index.html>.

161. Many copyright scholars have expressed this opinion, critiquing both the process and the results of legislative action. See generally Cohen, supra note 11, at $494 \mathrm{n} .114$ (noting the legislative expansion of copyright entitlements over the past two decades); Jessica Litman, Copyright Legislation and Technological Change, 68 OR. L. REv. 275 (1989) (describing how the participation of interested parties in the drafting process has warped legislation). 
too inuch or too little. An ideal result would balance the interests of creators, users, and the public. Currently, fair use has strayed from its role as balance keeper im its assessment of new markets. The bright line assumptions courts make regarding owuership of new markets coupled with strategic behavior by users of copyrighted works have distorted inarket effect analysis. Often fair use analysis of the market effect factor is reduced to an inquiry into whether there is a means to pay for a use.

Bright line rules are ill-suited to fair use. The structure of the fair use inquiry emphasizes fact-intensive analysis and a delicate balancing of interests. However, when principles are extracted from the narrow factual circumstances of fair use decisions, unforeseen results often occur. ${ }^{162}$ This is particularly true where courts do not conduct the proper inquiry in the first place. As a result, an ill-considered demal of fair use may wrongly grant an author new rights against users and subsequent authors.

In reforming market effect analysis, it may be necessary for courts to defer to the legislature where a denial of fair use would grant the owner the right to exploit a market which is neither traditional nor directly analogous to traditional markets. At a mininunn, Congress could articulate proper criteria for assessing rights in new markets. In the long run, Congress is better situated to make the difficult norınative decisions regarding new uses of copyrighted works and can best maintain copyright's constitutional balance.

162. Witness the fall-out from the Harper \& Row Publishers, Inc. v. Nation Enterprises, 471 U.S. 539 (1985) and Salinger v. Random House, Inc., 811 F.2d 90 (2d Cir. 1987), cert. denied, 484 U.S. 890 (1987) decisions: overly-broad readings of the Harper decision by lower courts created a presumption that the use of unpublished works was not fair. Congress had to restore the balance to fair use analysis via an amendment to 17 U.S.C. § 107. See Pub. L. No. 102-492, 106 Stat. 3145 (1992) (amending $\S 107$ to state that "[t]he fact that a work is unpublished shall not itself bar a finding of fair use if such finding is inade upon consideration of all the above factors"). 
[Vol. 88:1145 